\title{
Lack of $V_{1}$ vasopressin receptors in rabbit hepatocytes
}

\author{
Ann VANDEKERCKHOVE, Françoise MIOT, Stefaan KEPPENS and Henri DE WULF* \\ Afedling Biochemie, Campus Gasthuisberg, Fakulteit Geneeskunde, Katholieke Universiteit Leuven, B-3000 Leuven, Belgium
}

\begin{abstract}
Vasopressin does not induce glycogenolysis in rabbit hepatocytes; glucagon, angiotensin, phenylephrine and ATP are as potent as with rat hepatocytes, whereas isoprenaline is nearly 10000 times more potent in the rabbit. Binding studies of $\left[{ }^{3} \mathrm{H}\right]$ vasopressin reveal the complete absence of specific vasopressin receptors on rabbit liver plasma membranes. We verified that vasopressin acts as an antidiuretic and vasopressor agent in the rabbit. We conclude that there is a selective lack of $V_{1}$ vasopressin receptors in rabbit liver.
\end{abstract}

\section{INTRODUCTION}

Our present knowledge of the hormonal regulation of liver glycogenolysis, especially the cyclic AMP-independent $\mathrm{Ca}^{2+}$-mediated regulation, is mainly based on studies performed with male adult rat liver, where glucagon and the $\beta$-adrenergic agonists act via cyclic AMP, whereas vasopressin, angiotensin, ATP and the $\alpha_{1}$-adrenergic agonists act by increasing the cytosolic $\mathrm{Ca}^{2+}$ concentration.

It should be noted that for the adrenergic agonists clear-cut differences in sensitivity and effectiveness have been reported between young and adult rats [1,2], male and female rats [3], and between different animal species: dog [4] and rabbit [5] hepatocytes display a greater sensitivity to $\beta$-adrenergic agonists than do rat hepatocytes, whereas the liver of rabbit and guinea pig has more $\beta$ - than $\alpha$-receptors [6]. Finally, a complete lack of vasopressin receptors has been reported in the liver of $o b / o b$ mice as compared with their lean controls [7].

These examples of different sensitivities of livers to glycogenolytic agents prompted us to examine the effects of vasopressin, angiotension and ATP in the rabbit liver and compare them with the situation in the rat.

\section{MATERIALS AND METHODS}

\section{Materials}

$\left[{ }^{3} \mathrm{H}\right]$ Vasopressin was from Amersham International (Amersham, Bucks., U.K.). We have verified that $\left[{ }^{3} \mathrm{H}\right]$ vasopressin and the non-radioactive peptide possess the same glycogenolytic capacity, as estimated with rat liver cells.

Collagenase (type I) and [8-arginine]vasopressin were from Sigma Chemical Co. (St. Louis, MO, U.S.A.). Other chemicals were of the purest grade available.

The computer program 'Enzfitter' was purchased from Elsevier-Biosoft (Cambridge, U.K.).

\footnotetext{
Animals

We used male Wistar-strain albino rats $(200-250 \mathrm{~g}$ body wt.). Both male and female young ( $300-400 \mathrm{~g}$ body wt.) and adult (2-3 kg body wt.) mongrel rabbits were used. They had free access to water and were fed ad libitum with a standard laboratory chow. We have not detected any sex difference in the data obtained with the
}

rabbits, and consequently the data for the two sexes were pooled.

\section{Isolation of hepatocytes}

Rat liver cells were isolated and incubated as described previously [8]. Two techniques have been used for the isolation of rabbit hepatocytes. From adult rabbits, a liver sample $(20-30 \mathrm{~g})$ was taken and a catheter was promptly inserted into a vein; the subsequent procedure was that used in [8]. Owing to the very poor yield (less than $20 \%$ ) and the high percentage (up to 30 ) of TrypanBlue-stained cells, we preferred to use young rabbits for the isolation of hepatocytes [9]. This procedure resulted in high yields, with more than $95 \%$ of the cells excluding Trypan Blue.

\section{Plasma-membrane preparation}

Liver plasma membranes from rabbits (young and adult) and from rats were prepared as described in [10]. In the preparations so obtained, the stimulation of adenylate cyclase by glucagon was 2.5 -fold, and up to 9.5-fold by $\mathrm{NaF}$. Plasma membranes of the inner medulla of rabbit kidney were prepared as described in [11].

\section{Binding studies}

$\left[{ }^{3} \mathrm{H}\right]$ Vasopressin binding to purified plasma membranes was performed as described in ref. [12], except that Whatman GF/A filters were used. The stability of $\left[{ }^{3} \mathrm{H}\right]$ vasopressin was analysed as previously described for $\left[{ }^{3} \mathrm{H}\right]$ angiotensin [13]: its incubation for $20 \mathrm{~min}$ with rabbit liver plasma membranes resulted in a non-significant loss of glycogenolytic potency.

\section{Enzyme assays and protein determination}

Adenylate cyclase, glycogen phosphorylase and glycogen synthase were assayed as described in [14], [8] and [15] respectively. Protein content was determined as described in [16], with bovine serum albumin as standard.

\section{RESULTS AND DISCUSSION}

Rabbit hepatocytes, prepared from young animals, were challenged with glucagon, vasopressin and angiotensin. Fig. 1 illustrates that glucagon and angiotensin elicit a time-dependent activation of glycogen

\footnotetext{
* To whom reprint requests should be addressed.
} 

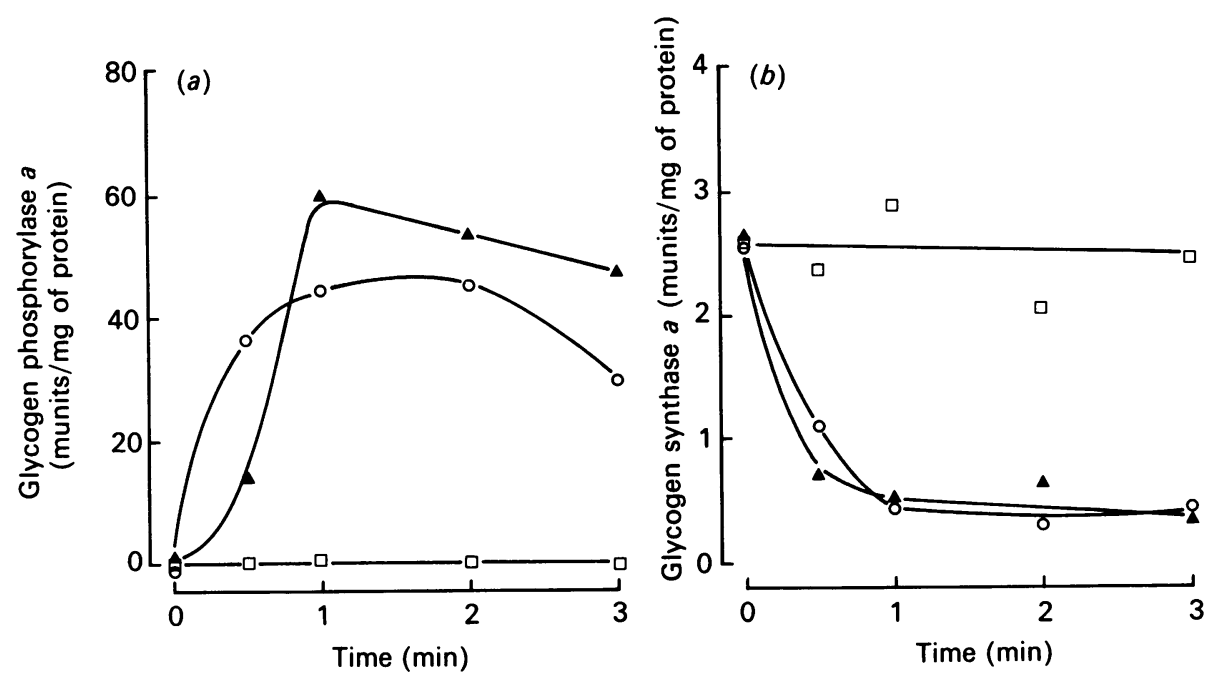

Fig. 1. Activation of phosphorylase and inactivation of glycogen synthase by glucagon, angiotensin and vasopressin

Hepatocytes from young rabbits were preincubated with $20 \mathrm{~mm}$-glucose and then challenged with $1 \mathrm{nM}$-glucagon ( $\Delta$ ), $20 \mathrm{nM}$ angiotensin $(O)$ or $20 \mathrm{~nm}$-vasopressin $(\square)$. At the times indicated, phosphorylase $(a)$ and synthase $(b)$ activities were measured. The curves shown are from one experiment and are representative of four independent observations with male and female rabbits.

phosphorylase and inactivation of glycogen synthase, but that vasopressin is without effect. This lack of vasopressin effect, which is not due to any rapid hormonolysis (its incubation for $1 \mathrm{~min}$ with rabbit hepatocytes resulted in a non-significant loss of glycogenolytic potency assayed with rat hepatocytes) prompted us to examine the effects of other glycogenolytic agonists.
Fig. 2 shows the glycogenolytic potency of glucagon, angiotensin, isoprenaline, vasopressin, ATP and phenylphrine: the absence of phosphorylase activation in rabbit hepatocytes is restricted to vasopressin. The degree of activation of phosphorylase obtained by angiotensin, phenylephrine and especially by ATP is less than that produced by glucagon or isoprenaline. We have checked that in the rabbit, as in the rat, the first three hormones

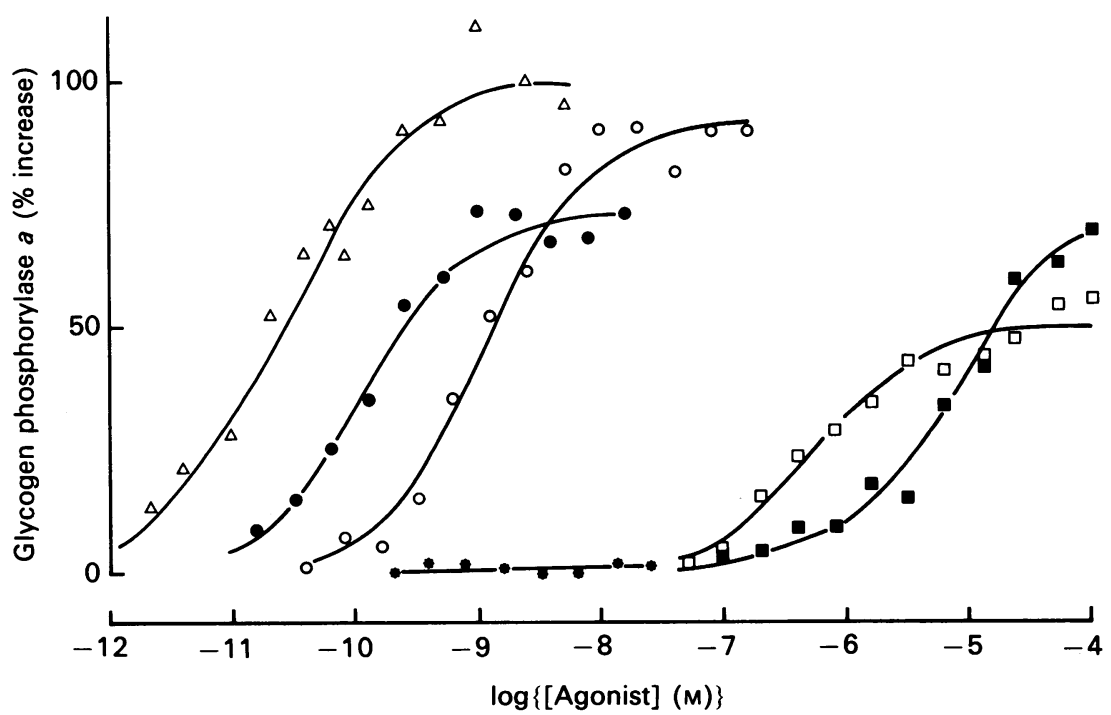

Fig. 2. Dose-response curves of phosphorylase activation by glucagon, angiotensin, isoprenaline, vasopressin, ATP and phenylephrine

Hepatocytes from young rabbits were preincubated for 20-30 min with $10 \mathrm{~mm}$-glucose and then treated for $1 \mathrm{~min}$ with increasing concentrations of glucagon $(\triangle)$, angiotensin $(\odot)$, isoprenaline $(O)$, vasopressin $(*)$ and phenylephrine $(\square)$, or for $20 \mathrm{~s}$ with increasing concentrations of ATP $(\square)$. Phosphorylase was then assayed, and the increases above control are expressed as percentages of the maximal increase observed after glucagon. Values shown are the means of four to five independent experiments with male and female rabbits. The lines drawn were computer-generated and represent the best Michaelis-Menten type fit of the data (agonist concentrations with their corresponding effects on phosphorylase) by using the 'Enzfitter' program. Basal values ranged from 3 to 8 munits $/ \mathrm{mg}$ of protein, and maximal values after glucagon were about 50 munits $/ \mathrm{mg}$ of protein. $K$ values (M): glucagon $1.9 \times 10^{-11}$, angiotensin $1.4 \times 10^{-10}$, isoprenaline $1 \times 10^{-9}$, ATP $5 \times 10^{-7}$, phenylephrine $3.4 \times 10^{-6}$. 


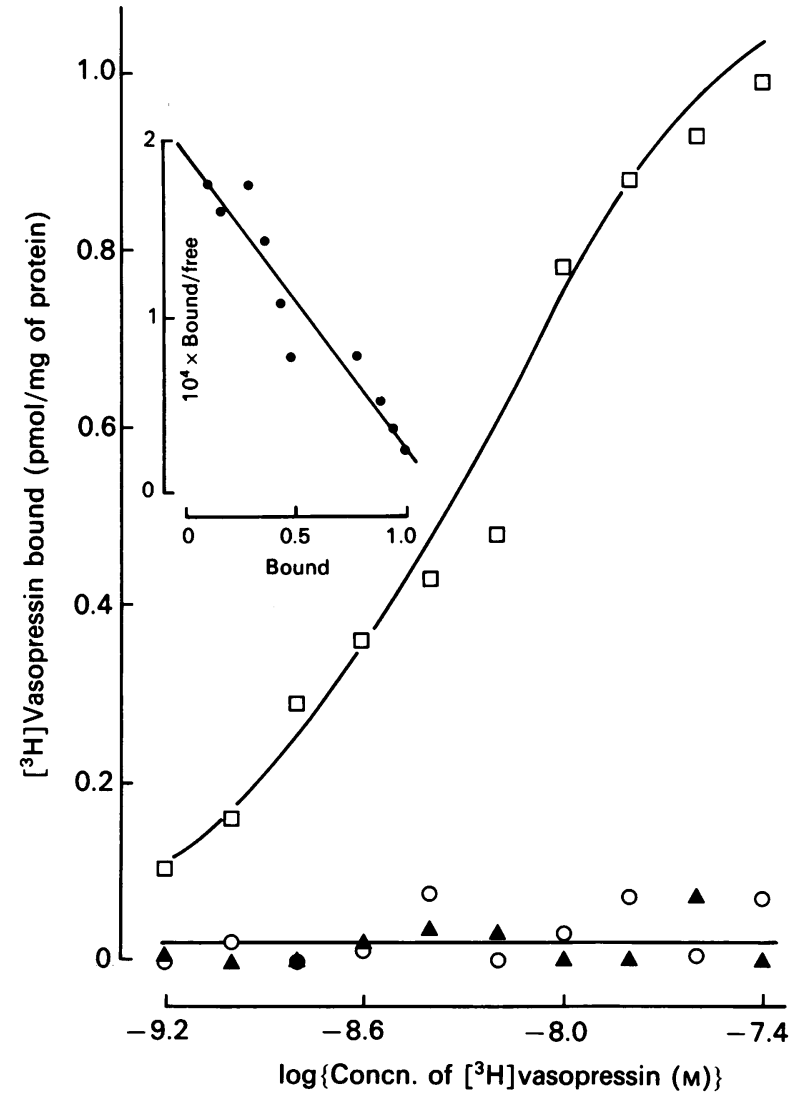

Fig. 3. Dose-dependency of the specific binding of $\left[{ }^{3} \mathrm{H}\right]$ vasopressin to purified rabbit and rat liver plasma membranes

Specific $\left[{ }^{3} \mathrm{H}\right]$ vasopressin binding is plotted as a function of the $\left[{ }^{3} \mathrm{H}\right]$ vasopressin concentration in the incubation medium with rat liver plasma membranes $(\square)$ or with plasma membranes prepared from young $(O)$ or adult rabbits (A). The inset shows the Scatchard plot for the binding of vasopressin to the rat liver plasma membranes. Bound/free values are given as litre $/ \mathrm{mg}$ of protein. Binding characteristics are given in the text.

have no effect on cyclic AMP contents, whereas glucagon and isoprenaline increase them from 2 to about 7 $\mathrm{pmol} / \mathrm{mg}$ of protein within $2 \mathrm{~min}$.

The $K_{\mathrm{A}}$ values (agonist concentrations to obtain halfmaximal activation) are given in the legend of Fig. 2. For glucagon, angiotensin, phenylephrine and ATP they are very similar to those obtained with rat hepatocytes [17]. In contrast, rabbit hepatocytes are nearly 10000 -fold more sensitive to isoprenaline than are rat cells $\left(K_{\mathrm{A}}=\right.$ $8.7 \times 10^{-6} \mathrm{M}$; the present study). This observation is in accordance with, and further extends, the differences reported in the literature $[5,6]$. Essentially the same results (not shown) have been obtained with hepatocytes prepared from adult rabbit.

In order to locate the defect of vasopressin action in rabbit liver, we searched for the presence of vasopressin receptors on rabbit liver plasma membranes. Fig. 3 shows that $\left[{ }^{3} \mathrm{H}\right]$ vasopressin does not bind to rabbit liver plasma membranes, in contrast with the binding observed with rat liver membranes. Scatchard analysis of the latter binding reveals one class of binding sites, with values for $K_{\mathrm{D}}(6 \mathrm{nM})$ and $V_{\max }(1.2 \mathrm{pmol} / \mathrm{mg}$ of protein) similar to those found previously with plasma membranes prepared in a slightly different way [12].

We have verified that the vasopressin preparation used in this study is active as an antidiuretic and vasopressor agent in the rabbit. Vasopressin $(10 \mu \mathrm{M})$ added to plasma membranes from rabbit kidney inner medulla stimulates the adenylate cyclase activity from 39 to $185 \mathrm{pmol} / \mathrm{min}$ per $\mathrm{mg}$ of protein, indicating that its antidiuretic activity is present. The pressor capacity of vasopressin was checked by measuring the blood pressure in two anaesthetized rabbits before and after the intravenous injection of 200 munits of vasopressin. Blood pressure $(\mathrm{mmHg})$ rose in a few seconds from 60 to 82 in one animal and from 35 to 80 in the other.

In conclusion, our data clearly show that the defect of vasopressin action in the rabbit appears to be restricted to the liver.

This work was supported by the Belgian F.G.W.O. and the 'Koningin Elizabeth Stichting'. We thank G. Cumps for skilful technical assistance, M. Coppens for carefully typing the manuscript, J. Stuyts for drawing the illustrations and L. Filez for help with the determination of blood pressure in anaesthetized rabbits.

\section{REFERENCES}

1. Blair, J. B., James, M. E. \& Foster, J. L. (1979) J. Biol. Chem. 254, 7579-7584

2. Bendeck, J. L. \& Noguchi, A. (1985) Pediatr. Res. 19, 862-868

3. Studer, R. K. \& Borle, A. B. (1982) J. Biol. Chem. 257, 7987-7993

4. Stevenson, R. W., Steiner, K. E., Green, D. R. \& Cherrington, A. D. (1984) Biochim. Biophys. Acta 804, 414-418

5. Rufo, G. A., Jr., Yorek, M. A. \& Ray, P. D. (1981) Biochim. Biophys. Acta 674, 297-305

6. Sulakhe, S. J., Pulga, V. B. \& Tran, S. (1988) Mol. Cell. Biochem. 83, 81-88

7. Assimacopoulos-Jeannet, F., Cantau, B., van de Werve, G., Jard, S. \& Jeanrenaud, B. (1983) Biochem. J. 216, 475-480

8. Vandenheede, J. R., Keppens, S. \& De Wulf, H. (1976) FEBS Lett. 61, 213-217

9. Proost, C., Carton, H. \& De Wulf, H. (1979) Biochem. Pharmacol. 28, 2187-2191

10. Kawai, Y., Powell, A. \& Arinze, I. J. (1986) J. Clin. Endocrinol. Metab. 62, 827-832

11. Rajerison, R., Marchetti, J., Roy, C., Bockaert, J. \& Jard, S. (1974) J. Biol. Chem. 249, 6390-6400

12. Cantau, B., Keppens, S., De Wulf, H. \& Jard, S. (1980) J. Receptor Res. 1, 137-168

13. Keppens, S., De Wulf, H., Clauser, P., Jard, S. \& Morgat, J. L. (1982) Biochem. J. 208, 809-817

14. Salomon, Y., Londos, C. \& Rodbell, M. (1974) Anal. Biochem. 58, 541-548

15. Doperé, F., Vanstapel, F. \& Stalmans, W. (1980) Eur. J. Biochem. 104, 137-146

16. Peterson, G. L. (1983) Methods Enzymol. 91, 95-119

17. Keppens, S. \& De Wulf, H. (1988) FEBS Lett. 233, 47-50 